\title{
HUBUNGAN PEMANFAATAN DANA BANTUAN OPERASIONAL KESEHATAN (BOK) DENGAN PENINGKATAN CAKUPAN KUNJUNGAN ANTENATAL K4 DI PUSKESMAS KOTA SERANG TAHUN 2014-2016
}

\author{
RELATION BETWEEN HEALTH OPERATIONAL AID FUND (BOK) WITH INCREASE IN K4 \\ ANTENATAL VISITI SCOPE AT SERANG CITY COMMUNITY HEALTH CENTERS YEAR 2014-2016 \\ Siti Nurul Laeliyah ${ }^{1 *}$ Mardiati Nadjib ${ }^{2}$ \\ ${ }^{1}$ Departemen Administrasi Kebijakan Kesehatan,Fakultas Kesehatan Masyarakat Universitas Indonesia \\ ${ }^{2}$ Departemen Administrasi Kebijakan Kesehatan,Fakultas Kesehatan Masyarakat Universitas Indonesia
}

\begin{abstract}
Health Operational Aid Fund (BOK) realization at Serang City Community Health Centers (CHC) through 2014-2016 has always reached $100 \%$ mark which more than $30 \%$ of the fund was allocated for maternal and children health each year However the achievement from maternal and children health scope especially on K4 antenatal visit was not proportional with the budget, instead each year a decreasing trend from proposed target $(75 \%)$ was observed thus the need of evaluation. This study was conducted at regional health agency and four CHCs (Banten Girang, Curug, Sawah Luhur and Serang Kota) with retrospective study case design and considering fund variables and scopes. The result shows lack of human and other resources in managing maternal and children health program; the lack of operational fund for preventive and promotive activities from regional government budget (APBD) and only rely on health operational fund; the lack of supervision in midwife records and reports, also the contract ending of trained cadres as the result of village chief replacement.
\end{abstract}

Keywords: community health centre, health operational fund, K4 antenatal visit

\section{ABSTRAK}

Realisasi dana Bantuan Operasional Kesehatan (BOK) di Puskesmas Kota Serang dari tahun 2014-2016 selalu mencapai $100 \%$ dengan alokasi dana untuk kegiatan KIA lebih dari $30 \%$ setiap tahunnya, namun tidak berbanding lurus dengan capaian cakupan pelayanan kesehatan ibu dan anak khususnya kunjungan antenatal K4 yang justru semakin tahun menunjukkan penurunan dari target yang ditetapkan $(75 \%)$ sehingga perlu dievaluasi. Penelitian dilakukan di Dinas Kesehatan dan 4 Puskesmas, yaitu Puskesmas Banten Girang, Curug, Sawah Luhur dan Serang Kota dengan studi kasus bersifat retrospektif dan mempertimbangkan variabe dana serta cakupan. Hasil penelitian menunjukkan bahwa semua Puskesmas kekurangan sumber daya manusia dan sarana prasarana dalam mengelola program KIA, ketersediaan dana operasional untuk kegiatan preventif dan promotif dari APBD tidak ada dan hanya mengandalkan dana BOK, kurangnya pengawasan pencatatan pelaporan bidan, serta putusnya kontak dengan kader yang sudah dilatih sebagai efek pergantian kepala desa.

Kata Kunci: Bantuan Operasional Kesehatan, Puskesmas, Kunjungan Antenatal K4

\section{Pendahuluan}

Otonomi daerah di Indonesia mulai diberlakukan pada tahun 1999 dengan dikeluarkannya Undang-Undang (UU) Nomor 22 Tahun 1999 tentang Otonomi Daerah. Seiring dengan bergulirnya waktu dan mengikuti perkembangan zaman serta evaluasi terhadap pelaksanaan otonomi daerah dilakukan penyesuaian terhadap UU tersebut sehingga pada saat ini yang berlaku adalah Undang-undang (UU) Nomor 23 Tahun 2014 tentang Pemerintahan Daerah (Pemda). Pelaksanaan otonomi daerah dimaksudkan untuk meningkatkan pelayanan publik dan meningkatkan kesejahteraan masyarakat dengan bekerja secara lebih efektif, efisien, inovatif dan leluasa dalam mengatur kebijakan di daerahnya(1). Namun, dalam pelaksanaan desentralisasi kesehatan di Indonesia yang terjadi adalah masih kurangnya perhatian dan prioritas dari pemerintah daerah terhadap pembangunan kesehatan di daerahnya. Salah satu buktinya, adalah politik anggaran kurang berpihak pada sektor kesehatan ${ }^{(2)}$. Para pengambil kebijakan di daerah lebih tertarik untuk mengalokasikan anggarannya pada sektor-sektor yang hasilnya dapat diukur dengan cepat dan nyata seperti pembangunan fisik dan sektor lainnya. Seharusnya hakikat desentralisasi kesehatan sesuai dengan paradigma sehat sebagai model pembangunan kesehatan di Indonesia, mengutamakan upayaupaya promotif tanpa mengabaikan upaya kuratif dan rehabilitative ${ }^{(3)}$. Maka dari itu, untuk menjawab masalah ketersediaan dana operasional di Puskesmas, Pemerintah Pusat meluncurkan program Bantuan Operasional Kesehatan (BOK) dalam upaya mendukung pencapaian SPM bidang Kesehatan dan sejalan dengan arah serta kebijakan Kementerian Kesehatan tahun 20102014 dan 2015-2019. 
Siti Nurul Laeliyah, dkk.: Hubungan Pemanfaatan Dana Bantuan Operasional Kesehatan (BOK)

Tabel 1. Penyerapan dana BOK di Kota Serang Tahun 2014-2016

\begin{tabular}{lccc}
\hline & Dana BOK 2014 (Rp) & Dana BOK 2015 (Rp) & Dana BOK 2016 (Rp) \\
\hline Dana Operasional Kegiatan di & $1.296 .000 .000(91,2 \%)$ & $1.240 .117 .000,-(84 \%)$ & $2.887 .680 .000,-(94 \%)$ \\
Puskesmas & $126.600 .000(8,8 \%)$ & $226.000 .000,-(16 \%)$ & $184.320 .000,-(6 \%)$ \\
Manajemen Operasional Dinkes & 1.422 .600 .000 & 1.466 .117 .000 & 3.072 .000 .000 \\
Total Dana BOK yang diterima & $1.422 .600 .000(100 \%)$ & $1.466 .117 .000(100 \%)$ & $3.072 .000 .000(100 \%)$ \\
\hline Total Penyerapan dana BOK &
\end{tabular}

Sumber: Data Evaluasi Akhir Tahun BOK Dinas Kesehatan Kota Serang tahun 2014-2016 (telah diolah kembali)

Kebijakan BOK ini masih berlangsung sampai tahun 2016 dengan adanya pengalihan anggaran di Pusat yang semula bersumber dari dana Tugas Pembantuan (Tahun 2010-2015) menjadi Dana Alokasi Khusus Non Fisik bidang Kesehatan (Tahun 2016). Pengalihan ini dimaksudkan untuk mempercepat pengalihan anggaran belanja Kementerian/Lembaga khususnya dekonsentrasi dan tugas pembantuan yang sudah menjadi urusan daerah ke Dana Alokasi Khusus serta mengakomodasi usulan kebutuhan dan prioritas daerah dalam mendukung pencapaian prioritas nasional (Proposal Based)(4). Dalam komitmen internasional yang dijabarkan dalam Millenium Development Goals (MDGs), pembangunan kesehatan menjadi perhatian yang penting dengan membuat target-target yang salah satunya terkait dengan bidang kesehatan ibu dan anak. Demikian juga ketika era MDGs berakhir dan beralih ke era Sustainable Development Goals (SDGs), kesehatan ibu dan anak masih menjadi prioritas penting. Di Indonesia, Angka Kematian Ibu (AKI) menjadi salah satu indikator penting dari derajat kesehatan masyarakat. Angka Kematian Ibu (AKI) berdasarkan SDKI 2012 sebesar 359 kematian per 100.000 kelahiran hidup. Padahal target MDGs pada tahun 2015, diharapkan AKI menurun menjadi 102 kematian per 100.000 kelahiran hidup. Dengan demikian terjadi kenaikan AKI dan target MDGs pada tahun 2015 tidak tercapai. Penyebab tersering kematian ibu adalah terkait masalah kehamilan, persalinan dan nifas yaitu perdarahan, eklamsia, dan infeksi(5). Maka dari itu, pentingnya kegiatan preventif dan promotif yang berkaitan dengan pelayanan kesehatan terhadap ibu baik dari masa hamil, bersalin dan nifas perlu ditingkatkan agar angka kematian ibu dapat menurun.

Salah satu pelayanan kesehatan ibu hamil diwujudkan melalui pemberian pelayanan antenatal sekurang-kurangnya 4 kali selama masa kehamilan, dengan distribusi waktu minimal
1 kali pada trimeseter pertama (usia kehamilan 0-12 minggu), 1 kali pada trimester kedua (usia kehamilan 12-24 minggu), dan 2 kali pada trimester ketiga (usia kehamilan 24-36 minggu). Indikator ini memperlihatkan akses pelayanan kesehatan terhadap ibu hamil dan tingkat kepatuhan ibu hamil dalam memeriksakan kehamilannya ke tenaga kesehatan. Selain itu, standar waktu pelayanan tersebut dianjurkan untuk menjamin perlindungan terhadap ibu hamil dan janin, berupa deteksi dini faktor risiko, pencegahan, dan penanganan dini komplikasi kehamilan. Persentase cakupan kunjungan ibu hamil K4 di Indonesia pada tahun 2015 mencapai $87,48 \%$, dengan provinsi yang memiliki cakupan K4 terendah Papua yaitu 24, 45\% dan tertinggi Kepulauan Riau yaitu $98,19 \%{ }^{(6)}$. Adanya Program Bantuan Operasional Kesehatan (BOK) yang diluncurkan Pemerintah berkontribusi meningkatkan cakupan K4. BOK dapat dimanfaatkan untuk kegiatan luar gedung, seperti pendataan, pelayanan di Posyandu, kunjungan rumah, sweeping kasus drop out, serta kemitraan bidan dan dukun yang diharapkan mampu mendorong tercapainya target cakupan K4.

Alokasi dana BOK yang diterima oleh Pemerintah Kota Serang cukup besar. Pada tahun 2014, alokasi dana BOK di Kota Serang sebesar Rp. 1.422.600.000,- dan mengalami peningkatan sebesar 3,05\% pada tahun 2015 menjadi Rp. 1.466.117.000,-. Kemudian pada tahun 2016, dengan adanya perubahan kebijakan sumber dana BOK dari Tugas Pembantuan (TP) menjadi Dana Alokasi Khusus (DAK) Non Fisik, alokasi dana BOK yang diterima oleh Kota Serang meningkat 209\% menjadi Rp. 3.072.000.000,-. Realisasi anggaran kegiatan BOK di 16 Puskesmas se-Kota Serang pada tahun 2014-2016 mencapai 100\%.

Alokasi dana untuk mendukung kegiatan kunjungan antenatal K4 sebenarnya sudah cukup besar. Dari total alokasi dana BOK Puskesmas tahun 2014 sebanyak 29,42\% (Rp. 381.325.000,- 
Tabel 2. Cakupan Pelayanan Kesehatan Kota Serang Tahun 2014-2016

\begin{tabular}{cccccc}
\hline No & Cakupan Program & Target & $\begin{array}{c}\text { Cakupan } \\
\text { sampai } \\
\mathbf{2 0 1 4}\end{array}$ & $\begin{array}{c}\text { Cakupan } \\
\text { sampai } \\
\mathbf{2 0 1 5}\end{array}$ & $\begin{array}{c}\text { Cakupan } \\
\text { sampai } \\
\mathbf{2 0 1 6}\end{array}$ \\
\hline 1 & Cakupan kunjungan ibu hamil $(\mathrm{K} 4)$ & $75 \%$ & $68,88 \%$ & $71,27 \%$ & $69,45 \%$ \\
\hline
\end{tabular}

Sumber: Data Dinas Kesehatan Kota Serang tahun 2014-2016 (telah diolah kembali)

dari Rp. 1.296.000.000,-) alokasi dana sudah ditujukan untuk mendukung upaya peningkatan cakupan kunjungan K4. Kemudian persentasenya meningkat pada tahun 2015 menjadi $34,11 \%$ (Rp. 422.980.000,- dari Rp. 1.240.117.000,-), dan semakin meningkat lagi pada tahun 2016 menjadi $39,25 \%$ (Rp. 1.133.502.000,- dari Rp. 2.887.680.000,-). Hasil evaluasi menunjukkan meskipun anggaran BOK pada tahun 2014-2016 mengalami peningkatan dengan penyerapan anggaran di semua puskesmas sudah maksimal, namun tidak berbanding lurus dengan capaian cakupan pelayanan kesehatan ibu dan anak khususnya kunjungan antenatal K4 yang justru semakin tahun menunjukkan penurunan.

TRealisasi dana BOK di Kota Serang dari tahun 2014-2016 selalu mencapai 100\%. Dengan tingginya serapan dana tersebut serta meningkatnya jumlah alokasi dana setiap tahunnya bahkan pada tahun 2016 mencapai dua kali lipat dari anggaran BOK di tahun sebelumnya, seharusnya diimbangi dengan peningkatan pelayanan kesehatan ibu dan anak khususnya cakupan kunjungan antenatal K4 karena dana BOK dapat digunakan untuk membiayai kegiatan promotif dan preventif di luar gedung, khususnya transport petugas Puskesmas untuk kunjungan rumah ibu hamil, pendataan sasaran, pendampingan kelas ibu hamil bahkan membina kemitraan bidan dengan dukun. Namun hasil capaian kunjungan antenatal K4 di Kota Serang tidak mencapai target bahkan mengalami penurunan. Maka dari itu, perlu diketahui mengenai Hubungan Pemanfaatan Dana Bantuan Operasional Kesehatan (BOK) dengan Peningkatan Cakupan Kunjungan Antenatal K4 di Puskesmas Kota Serang Tahun 2014-2016.

Tujuan Umum Penelitian ini adalah Menganalisis Hubungan Pemanfaatan Dana Bantuan Operasional Kesehatan (BOK) Terhadap Peningkatan Cakupan Kunjungan Antenatal K4 di Puskesmas Kota Serang Tahun 2014-2016. Tujuan khususnya yaitu Mendapatkan gambaran rencana usulan kegiatan yang bersumber dana BOK pada tahun 2014-2016; Menganalisis pemanfaatan dana BOK di Puskesmas Kota Serang tahun 2014-2016;
Menganalisis mengenai cakupan KIA dan kendalakendala mengenai sumber daya manusia, sarana prasarana, dana operasional pada tahun 20142016; Menganalisis pelaksanaan dan pembinaan kegiatan dalam keterkaitannya dengan pemanfaatan dana BOK Puskesmas pada tahun 2014-2016; dan Menganalisis hubungan pemanfaatan dana BOK dengan cakupan kunjungan antenatal K4 di Puskesmas Kota Serang tahun 2014-2016.

\section{Metode Penelitian}

Penelitian ini menggunakan studi kasus dengan desain penelitian retrospektif. Sumber data yang dipakai berupa data primer dan sekunder. Data primer diperoleh secara langsung dari informan (17 orang) melalui proses wawancara mendalam menggunakan pedoman wawancara dan alat bantu rekam, sedangkan data sekunder dikumpulkan melalui proses penelaahan dokumen yang berhubungan dengan kebijakan program KIA khususnya kegiatan yang mendukung kunjungan K4 yang dibiayai oleh dana BOK pada tahun 2014-2015 serta dana BOK DAK Non Fisik tahun 2016 dalam bentuk aturan, perundang-undangan, laporan, petunjuk teknis kegiatan dan dokumen penting lainnya.

Peneliti menentukan 4 Puskesmas sebagai lokasi penelitian dengan mempertimbangkan kriteria yaitu Puskesmas yang cakupan kunjungan K4nya tinggi dengan Puskesmas yang cakupannya masih rendah dalam rentang tahun 2014-2016 yang dilakukan pada bulan April-Mei 2017. Data di analisis menggunakan teknik analisis isi (content analysis) yang dimulai dengan melakukan coding terhadap istilah-istilah atau penggunaan kata dan kalimat yang relevan, yang paling banyak muncul dalam komunikasi. Kemudian dilakukan klasifikasi terhadap coding yang sudah dibuat. Hasil analisis lalu dideskripsikan dalam bentuk narasi dan matriks.

\section{Hasil dan Pembahasan \\ Sumber Daya Manusia}

Di Puskesmas yang memiliki cakupan K4 tertinggi yaitu Puskesmas Sawah Luhur memiliki 
wilayah kerja lebih sedikit karena hanya 1 desa dengan kondisi jumlah posyandu 15 buah. Jika dilihat dari tupoksi sebagai bidan dan pengelola KIA, secara jumlah sudah cukup. Namun jika dilihat dari beban kerja seluruh pegawai PNS di Puskesmas termasuk kepala puskesmas dan kepala TU puskesmas berjumlah 11 orang, dan magang 13 orang dimana harus menjalankan banyak program yang ada di Puskesmas sekaligus melayani masyarakat. Peran kepala puskesmas dalam mengoptimalkan SDM di puskesmas ini cukup besar dengan melakukan pengaturan kerja staf setiap harinya serta pengawasan yang cukup baik. Selain itu, kepala puskesmas juga aktif turun ke lapangan membantu kegiatan seperti posyandu ataupun penyuluhan apabila ada staf yang berhalangan hadir. Jadi, walaupun bidan yang ada di Puskesmas Sawah Luhur memegang program tambahan sebanyak 2 sampai 3 program diluar program KIA, namun karena adanya manajemen yang baik dengan mengoordinasikan seluruh petugas yang ada di Puskesmas, maka pengelolaan program KIA khususnya cakupan K4 hasilnya baik juga.

Begitupun dengan puskesmas Serang Kota. Jumlah pegawai PNS 38 orang dan pegawai magang 13 orang dengan area kerja di 4 kelurahan dan 25 posyandu. Area kerja Puskesmas Serang Kota ini berada di wilayah kelurahan yang padat penduduknya karena terletak di tengah-tengah Kota Serang. Setiap harinya kunjungan pasien di Puskesmas Serang Kota paling tinggi dibandingkan dengan puskesmas lainnya. Pemegang program KIA di puskesmas termasuk bidan desa dipegang seluruhnya oleh bidan PNS yang berjumlah 10 orang. Begitupun dengan pelayanan ke masyarakat baik dalam gedung maupun luar gedung (posyandu, pusling, poskesdes, dsb) bidan PNS aktif terlibat termasuk juga melakukan administrasi pencatatan dan pelaporan. Setiap hari antar bidan desa dan pemegang program KIA ada komunikasi yang dilakukan untuk membicarakan kegiatan pada hari tersebut dan program berjalan baik lewat tatap muka langsung ataupun melalui alat komunikasi. Selain itu, adanya aturan disiplin kerja yang diterapkan oleh kepala puskesmas Serang Kota terhadap pegawai. Setiap minggu diadakan pertemuan rutin puskesmas membahas program termasuk target dan cakupan, pelaporan kegiatan serta permasalahan yang dihadapi petugas. Kepala puskesmas juga sering mengingatkan pada petugasnya mengenai pentingnya menunjukkan etos kerja yang baik karena ada tanggung jawab yang harus diemban karena petugas Puskesmas Serang Kota selain sudah digaji oleh pemerintah juga menerima dana jasa pelayanan kapitasi JKN dalam jumlah besar dibandingkan dengan puskesmas lainnya.

Pada puskesmas yang cakupannya rendah yaitu Puskesmas Banten Girang dan Curug, didapat bahwa pengawasan dari kepala puskesmas dan bidan koordinator terutama mengenai pencatatan dan pelaporan kegiatan masih lemah. Jumlah tenaga PNS di Puskesmas Banten Girang 20 orang termasuk kepala puskesmas dengan area kerja 4 desa yang luas dan 25 posyandu. Secara jumlah tenaga bidan ada 8 orang, dan 4 (empat) diantaranya menjadi bidan desa. Upaya optimalisasi SDM di Puskesmas Banten Girang sebenarnya sudah dilakukan oleh kepala puskesmas, dengan membuat jadwal masing-masing kegiatan namun monitoring yang dilakukan masih kurang. Berdasarkan wawancara di lapangan, dikarenakan keterbatasan tenaga PNS dan beban kerja yang besar, akhirnya pegawai magangpun menjadi pemegang salah satu program yaitu Kesehatan Lingkungan. Pengelolaan program KIA di Puskesmas Banten Girang khususnya bidan desa dipegang oleh bidan PNS namun karena mereka mempunyai tugas tambahan seperti menjadi pemegang program lainnya serta menjadi bendahara, menjadikan pencatatan dan pelaporannya lalai dan tidak rapi. Kendala lainnya adalah sulitnya melakukan pertemuan rutin bulanan antar bidan dan pengelola program KIA di Puskesmas Banten Girang sehingga pengawasan bidan koordinator terhadap pencatatan dan pelaporan kegiatan yang telah dilakukan menjadi kurang.

Hal yang sama terjadi Puskesmas Curug. Puskesmas Curug memiliki tenaga bidan sebanyak 11 orang PNS dengan area kerja 1 kecamatan yang terdiri dari 10 desa/kelurahan dan 13 posyandu. Tujuh dari sepuluh desa di area Puskesmas Curug dipegang oleh bidan PTT yang berusia muda, sedangkan bidan PNS lainnya memegang program selain KIA, bahkan ada yang menjadi bendahara. Kendala lainnya juga, bidan desa di Puskesmas Curug tidak tinggal di tempat sehingga menyulitkan petugas dalam menemukan ibu hamil yang menjadi sasaran kegiatan kunjungan antenatal K1 murni (0-12 minggu). Padahal kunjungan antenatal $\mathrm{K} 1$ murni berperan penting dalam penentuan cakupan kunjungan antenatal K4. Kondisi kecamatan Curug yang sebagian wilayah masih pedesaan juga berpengaruh 
terhadap pola pikir masyarakatnya. Keberadaan dukun beranak masih banyak ditemukan di wilayah kerja Puskesmas Curug. Masyarakat masih lebih percaya untuk memeriksakan kondisi kehamilannya pada dukun beranak daripada bidan desa yang PTT yang berusia muda dan dianggap kurang berpengalaman. Selain itu juga, kondisi kader kesehatan yang sudah dibina oleh petugas puskesmas berganti akibat kebijakan kepala desa yang baru. Akibatnya, koordinasi antara bidan desa dan kader menjadi terhambat dan masalah pencatatan juga pelaporan kegiatan khususnya KIA juga masih kurang.

Pengelolaan BOK pada 4 (empat) Puskesmas yang diteliti juga mengalami kendala yang hampir sama, yaitu ketersediaan pegawai yang melaksanakan pengelolaan tidak sesuai dengan beban kerja yang harus dilaksanakan. Hampir sebagian besar pengelola BOK juga diberikan tugas mengelola program lainnya, bahkan karena keterbatasan tenaga pada Puskesmas pengelolaan BOK ini dilaksanakan oleh Bidan atau Perawat. Jika ditinjau dari kemampuan dan tugas, maka sudah pasti tidak sesuai. Kendala lain dalam pengelolaan BOK juga adanya pergantian Bendahara sebagai pengelola yang terjadi hampir setiap tahun. Bendahara yang sebelumnya telah diberikan pelatihan dan memahami tugas yang harus dilaksanakan karena berganti orang, maka dari itu Bendahara yang baru harus belajar dari awal kembali yang pada akhirnya menghambat proses pemanfaatan BOK dan penyusunan pertanggungjawaban.

Selain dari segi jumlah, kompetensi pegawai dalam melaksanakan tugas juga menjadi variabel penting yang harus dianalisa untuk mengetahui apakah suatu program dapat berjalan baik atau tidak. Ketidaksesuaian antara kompetensi yang dimiliki oleh pegawai dengan kompetensi yang dibutuhkan dalam jabatan untuk melaksanakan tugas dapat berpengaruh pada rendahnya tingkat keberhasilan tugas. Kompetensi yang diperlukan dalam pengelolaan KIA cukup banyak, dengan demikian dibutuhkan juga banyak pelatihan. Keterbatasan anggaran mengakibatkan alokasi peserta pelatihan tidak sesuai dengan jumlah pengelola KIA yang membutuhkan peningkatan kompetensi.

Pengelolaan BOK terkendala oleh ketidaksesuaian antara kualifikasi pendidikan yang dibutuhkan dengan pelaksana tugas atau pemangku jabatan. Latar belakang pendidikan yang dibutuhkan dalam mengelola dana BOK adalah pegawai dengan kualifikasi pendidikan dibidang keuangan atau yang terkait, sedangkan sebagian besar Bendahara BOK adalah Bidan dan Perawat. Meskipun ada bimbingan teknis yang diberikan secara berkala, namun pelaksanaan pemanfaatan BOK dan pertanggungjawabannya tidak dapat secara maksimal dikerjakan. Maka, selain adanya pelatihan yang diberikan juga perlu adanya kesepakatan bersama antara Dinas Kesehatan dengan Pengelola Keuangan BOK Puskesmas mengenai ketentuan lamanya waktu jabatan selama menjadi pengelola keuangan BOK di Puskesmas, agar pergantian pengelola ini tidak terjadi setiap tahun.

\section{Sarana Prasarana}

Sarana di 4 (Empat) Puskesmas berupa ruang administrasi bagi pengelola keuangan BOK di Puskesmas sebenarnya sudah tersedia. Akan tetapi, dari segi prasarana dan alat penunjang seperti komputer, printer, ATK dan lainnya masih kurang. Komputer yang tersedia sudah cukup lama kondisinya sehingga kinerjanya lambat. Selain itu juga sering digunakan secara bersama oleh staf di Puskesmas dan jarang diperbaharui antivirusnya sehingga menimbulkan kekhawatiran pengelola keuangan BOK di Puskesmas akan keamanan berkas-berkas administrasi yang tersimpan didalamnya. Pada akhirnya, pengelola keuangan BOK lebih memilih untuk membawa laptop pribadi agar lebih nyaman dan aman dalam mengerjakan administrasi pelaporan pertanggungjawaban keuangan BOK. Sementara untuk printer dan ATK walau dalam kondisi terbatas namun dirasakan cukup pada beberapa puskesmas.

Sarana dan prasarana program KIA di semua Puskesmas yang diteliti juga masih sangat kurang terutama untuk kegiatan di luar gedung khususnya kegiatan preventif dan promotif yang kegiatannya dibiayai oleh dana BOK. Sarana berupa posyandu dan poskesdes, sebagian besar di Puskesmas tidak memiliki bangunan untuk Posyandu dan hanya sedikit untuk Poskesdes. Selama ini, Posyandu hanya dilaksanakan di rumah warga dengan peralatan penunjang seadanya sehingga masyarakat masih banyak yang segan untuk menggunakan pelayanan kesehatan ini. Kondisi alat penunjang dalam melakukan pelayanan kesehatan KIA di luar gedung juga masih kurang dan banyak yang rusak terutama Doppler dan USG. Di wilayah penelitian ada dua USG yang kondisinya tidak bisa dipakai karena layar USGnya bermasalah (Puskesmas Serang Kota) dan 
Siti Nurul Laeliyah, dkk.: Hubungan Pemanfaatan Dana Bantuan Operasional Kesehatan (BOK)

Tabel 3. Penyerapan Dana BOK untuk Program KIA yang Mendukung Cakupan K4 di Puskesmas Tahun 2014-2016

\begin{tabular}{lrrrrrrrrr}
\hline \multirow{2}{*}{ Puskesmas } & \multicolumn{3}{c}{2014} & \multicolumn{2}{c}{2015} & \multicolumn{2}{c}{2016} \\
\cline { 2 - 10 } & $\begin{array}{c}\text { PAGU } \\
\text { (dalam juta) }\end{array}$ & \multicolumn{2}{c}{$\begin{array}{c}\text { KIA } \\
\text { (dalam juta) }\end{array}$} & $\begin{array}{c}\text { PAGU } \\
\text { (dalam juta) }\end{array}$ & $\begin{array}{c}\text { KIA } \\
\text { (dalam juta) }\end{array}$ & $\begin{array}{c}\text { PAGU } \\
\text { (dalam juta) }\end{array}$ & $\begin{array}{c}\text { KIA } \\
\text { (dalam juta) }\end{array}$ \\
\hline Banten Girang & 75,705 & 28,130 & $37,16 \%$ & 81,352 & 35,720 & $43,91 \%$ & 181,742 & 72,212 & $39,73 \%$ \\
Curug & 116,650 & 52,825 & $45,29 \%$ & 110,778 & 65,380 & $59,02 \%$ & 263,644 & 124,548 & $47,24 \%$ \\
Sawah Luhur & 28,420 & 6,175 & $21,73 \%$ & 31,367 & 9,450 & $30,13 \%$ & 95,638 & 19,270 & $20,15 \%$ \\
Serang Kota & 88,755 & 31,160 & $35,11 \%$ & 91,186 & 39,270 & $43,07 \%$ & 196,866 & 83,367 & $42,35 \%$ \\
\hline
\end{tabular}

Sumber: Dinas Kesehatan Kota Serang Tahun 2014-2016 (data telah diolah kembali)

Tabel 4. Penyerapan Dana BOK untuk mendukung Cakupan Antenatal K4 di Puskesmas tahun 2014

\begin{tabular}{lcrrr}
\hline \multicolumn{1}{c}{ PUSKESMAS } & DANA & SASARAN & TARGET & CAPAIAN \\
\hline BANTEN GIRANG & $22,890,000$ & 689 & 370 & $53.70 \%$ \\
CURUG & $39,725,000$ & 1118 & 534 & $47.76 \%$ \\
SERANG KOTA & $27,230,000$ & 1210 & 1074 & $88.76 \%$ \\
SAWAH LUHUR & $4,865,000$ & 202 & 172 & $85.15 \%$ \\
\hline
\end{tabular}

Tabel 5. Penyerapan Dana BOK untuk mendukung Cakupan Antenatal K4 di Puskesmas tahun 2015

\begin{tabular}{lrrrr}
\hline \multicolumn{1}{c}{ PUSKESMAS } & \multicolumn{1}{c}{ DANA } & SASARAN & TARGET & \multicolumn{2}{c}{ CAPAIAN } \\
\hline BANTEN GIRANG & $25,320,000$ & 760 & 446 & $58.68 \%$ \\
CURUG & $39,380,000$ & 1234 & 628 & $50.89 \%$ \\
SERANG KOTA & $31,470,000$ & 1335 & 1145 & $85.77 \%$ \\
SAWAH LUHUR & $6,850,000$ & 223 & 190 & $85.20 \%$ \\
\hline
\end{tabular}

Tabel 6. Penyerapan Dana BOK untuk mendukung Cakupan Antenatal K4 di Puskesmas tahun 2016

\begin{tabular}{|c|c|c|c|c|}
\hline PUSKESMAS & DANA & SASARAN & TARGET & CAPAIAN \\
\hline BANTEN GIRANG & $67,812,000$ & 760 & 420 & $55.26 \%$ \\
\hline CURUG & $113,548,000$ & 1234 & 599 & $48.54 \%$ \\
\hline SERANG KOTA & $79,917,000$ & 1335 & 1214 & $90.94 \%$ \\
\hline SAWAH LUHUR & $18,170,000$ & 223 & 200 & $89.69 \%$ \\
\hline
\end{tabular}

Sumber: Dinas Kesehatan Kota Serang tahun 2014-2016 (data telah diolah kembali)

adaptornya hilang (Puskesmas Sawah Luhur). Doppler di semua puskesmas, kondisinya rusak karena sering dipakai, dan apabila rusak tidak dapat diperbaiki lagi. sehingga khususnya bidan desa menggunakan Doppler milik pribadi saat melakukan kegiatan pelayanan kesehatan ke masyarakat atau secara bergantian dengan bidan lainnya untuk menggunakan Doppler di Puskesmas yang masih baik kondisinya.

\section{Dana Operasional}

Besaran dana BOK untuk kegiatan KIA di Puskesmas memang cukup besar. Pada tahun 2014-2016, Puskesmas yang cakupan K4nya rendah yaitu Puskesmas Banten Girang dan Curug justru memiliki dana BOK yang lebih besar persentasenya dibandingkan Puskesmas yang cakupannya tinggi (Puskesmas Sawah Luhur). Kegiatan KIA yang mendukung kunjungan K4 pada tahun 2014-2016 di setiap puskesmas pun sama. Perbedaannya antara tiap puskesmas adalah alokasi dana BOK dibagi berdasarkan jumlah posyandu, luas wilayah dan jumlah masyarakat. Artinya dana BOK yang sudah diterima oleh masing-masing puskesmas sudah proporsional, sesuai dengan beban kerja di wilayah puskesmas.

Pada puskesmas yang cakupan K4nya rendah, petugas hanya berfokus pada kegiatan 
yang dibiayai saja. Adapun kegiatan yang tidak dibiayai, kurang mendapat perhatian. Petugas menjadi kurang termotivasi untuk mencari sasaran ibu hamil muda sehingga target kunjungan K4 pun tidak tercapai. Berbeda halnya dengan puskesmas yang cakupannya tinggi dengan pengawasan yang baik dari kepala puskesmas, petugas juga mengerjakan kegiatan KIA lain walaupun tidak dibiayai seperti kunjungan ibu hamil risiko tinggi, kegiatan kelas ibu hamil yang tetap berjalan, dan sebagainya.

Berdasarkan data diatas, jumlah sasaran ibu hamil di Puskesmas yang cakupan K4nya yaitu Puskesmas Banten Girang dan Curug memang lebih banyak jika dibandingkan sasaran ibu hamil di Puskesmas Sawah Luhur, namun tidak lebih besar dari jumlah sasaran ibu hamil di Puskesmas Serang Kota. Walaupun jumlah sasaran ibu hamil di Puskesmas Serang Kota lebih banyak dibandingkan ketiga puskesmas lainnya namun capaian K4nya lebih baik. Dilihat dari penyerapan dana BOK untuk mendukung kegiatan antenatal K4, Puskesmas Curug menyerap jumlah dana paling besar dibandingkan ketiga puskesmas lainnya yaitu Rp. 39.725.000,- pada tahun 2014 dan meningkat di tahun 2016 menjadi Rp. 113.548.000,-. Penyerapan dana ini tidak diiringi dengan capaian K4nya dimana Puskesmas Curug justru terendah dibandingkan dengan Puskesmas lainnya yaitu 47,76\% di tahun 2014; pada tahun 2015 menjadi 50,89\% dan pada tahun 2016 menurun menjadi 48,54\%.

Penyerapan dana BOK untuk kegiatan K4 terendah di Puskesmas Sawah Luhur yaitu Rp. 4.865.000,- pada tahun 2014 dan meningkat pada tahun 2016 menjadi Rp. 18.170.000,- , namun dana BOK ini memberikan pengaruh baik sehingga capaian K4 di Puskesmas Sawah Luhur selalu meningkat dan diatas target yang ditetapkan oleh Pemkot Serang (>85\% dari target $75 \%$ ). Puskesmas Serang Kota yang memiliki jumlah sasaran ibu hamil yang terbanyak (2014 yaitu 1210 orang; 2015 dan 2016 yaitu 1335 orang) dan menyerap dana BOK untuk kegiatan K4 juga banyak (2014 yaitu Rp. 27.230.000,-; 2015 yaitu Rp. 31.470.000,-; 2016 yaitu Rp. 79.917.000,-). Penyerapan dana ini diimbangi dengan capaian K4 yang juga baik bahkan tertinggi dibandingkan 3 Puskesmas penelitian lainnya dan seluruh Puskesmas di Kota Serang.

Permasalahan yang dihadapi oleh keempat puskesmas yang diteliti yaitu ketersediaan dana untuk kegiatan KIA yang terlambat, karena menurut aturan yang berlaku di Dinas Kesehatan, dana BOK dapat dicairkan apabila Iaporan pertanggungjawaban sudah diserahkan Puskesmas ke Dinas Kesehatan. Sehingga kegiatan berjalan dengan dana talangan dari uang pribadi pengelola keuangan BOK Puskesmas ataupun dana talangan kas Puskesmas.

Penyerapan dana BOK di Puskesmas Kota Serang selama tahun 2014-2016 selalu mencapai $100 \%$. Pada petunjuk teknis BOK tahun 2014-2015 diberikan kemudahan dalam hal pertanggungjawaban kegiatan yang telah dilakukan. SPJ kegiatan yang didanai BOK 20142015 lebih sederhana dibandingkan SPJ kegiatan yang didanai BOK tahun 2016 yang lebih rinci namun tetap dapat dilaksanakan oleh pengelola keuangan BOK Puskesmas dengan baik. Selain itu, adanya kemudahan dalam pencairan dana dari Dinas Kesehatan ke Puskesmas walaupun pencairan dana tersebut selalu terlambat dan diberikan usai kegiatan. Perencanaan kegiatan BOK juga sudah mengacu pada Rencana Usulan Kegiatan yang sudah dibuat oleh Puskesmas disesuaikan dengan cakupan program dan prioritas masalah yang ada di Puskesmas. Maka dari itu, penyerapan dana BOK di Kota Serang selalu mencapai $100 \%$ pada tahun 2014-2016.

\section{Penyusunan Rencana Usulan Kegiatan}

Sesuai Kepmenkes Nomor 128/Menkes/ SK/II/2004 tentang Kebijakan Dasar Puskesmas, Kementerian Kesehatan menerbitkan buku pedoman Manajemen Puskesmas yang terdiri dari Pedoman Perencanaan Tingkat Puskesmas, Pedoman Lokakarya Mini Puskesmas, dan Pedoman Penilaian Kinerja Puskesmas. Langkah pertama dalam mekanisme perencanaan tingkat Puskesmas adalah menyusun Rencana Usulan Kegiatan (RUK) ${ }^{(7)}$. RUK yang disusun oleh Puskesmas di kota Serang termasuk 4 (Empat) puskesmas yang diteliti merupakan RUK tahun mendatang yang disusun berdasarkan hasil kajian pencapaian kegiatan tahun sebelumnya dan diharapkan proses penyusunan RUK telah selesai dilaksanakan di Puskesmas pada akhir bulan Januari tahun berjalan.

Berdasarkan informasi yang didapat dari informan di Puskesmas, sebagian besar informan mengatakan bahwa RUK disusun dengan melihat cakupan tahun sebelumnya dan kebutuhan puskesmas berdasarkan permasalahan yang ada. RUK Puskesmas di Kota Serang khususnya di lokasi penelitian direncanakan bersama oleh tiap pemegang program yang ada di Puskesmas 
dan dikonsultasikan ke Pemegang Program yang ada di Dinas Kesehatan. Setelah itu, pemegang program Puskesmas menyerahkan usulan kegiatan pada Kepala Puskesmas untuk diajukan ke Dinas Kesehatan. Pada tahap ini, puskesmas sudah mematuhi mekanisme penyusunan RUK yang telah dibuat oleh Pemerintah Pusat (Kementerian Kesehatan RI).

\section{Verifikasi Rencana Usulan Kegiatan (RUK)}

Rencana Usulan Kegiatan diajukan ke Dinas Kesehatan maka selanjutnya Tim Pengelola BOK Dinas Kesehatan melakukan proses verifikasi. Verifikasi dilakukan dengan melihat satu persatu jenis kegiatan, jumlah dana, dan sumber dana yang akan digunakan oleh Puskesmas. Aspek yang menjadi perhatian utama dalam proses verifikasi yaitu memperhatikan indikator SPM, sinkronisasi dengan kegiatan di Dinkes sampai dengan ketentuan proporsi kegiatan yang ada dalam Juknis BOK. Setelah proses verifikasi oleh masing-masing pemegang program, lalu dibahas bersama oleh Tim Pengelola BOK Dinas Kesehatan disinkronkan dengan program di bidang lain. Namun berdasarkan wawancara dengan pengelola keuangan BOK di 4 (empat) Puskesmas yang diteliti, sebagian besar mereka tidak mengetahui bagaimana proses verifikasi yang berlangsung di Dinas Kesehatan.

\section{Penetapan Rencana Usulan Kegiatan}

Berdasarkan Pedoman perencanaan tingkat Puskesmas yang dibuat oleh Kementerian Kesehatan, langkah penyusunan RPK adalah dengan mempelajari alokasi kegiatan dan biaya yang sudah disetujui; membandingkan alokasi kegiatan yang sudah disetujui dengan RUK yang diusulkan dan situasi pada saat penyusunan RPK; menyusun rancangan awal, rincian dan volume kegiatan yang akan dilaksanakan serta sumber daya pendukung menurut bulan dan lokasi pelaksanaan; mengadakan lokakarya mini tahunan untuk membahas kesepakatan RPK; serta membuat RPK yang telah disusun dalam bentuk matriks ${ }^{(8)}$. Menurut keterangan dari informan kunci di Dinas Kesehatan yaitu Pengelola BOK Dinkes, RPK disusun dengan memprioritaskan program basic six, selain itu juga dengan mempertimbangkan jumlah penduduk, luas wilayah, ketersediaan SDM dan juga ketersediaan dana lain seperti JKN. Kemudian, berdasarkan keterangan informan dari Puskesmas bahwa RPK disusun oleh Tim Pengelola Dinas Kesehatan lalu puskesmas diminta untuk membuat PoA tahunan dan bulanan dengan mengacu pada RPK yang telah disepakati oleh Tim Pengelola Dinas Kesehatan. RPK diuraikan dalam PoA Puskesmas baik tahunan dan bulanan dan sebelum disetujui, Dinas Kesehatan dan Puskesmas duduk bersama untuk membahas kegiatan didalamnya.

\section{Pelaksanaan Kegiatan}

Mengenai pelaksanaan kegiatan sendiri sudah sesuai dengan yang direncanakan dalam PoA tahunan dan bulanan. Berdasarkan keterangan informan dari Puskesmas, pelaksanaan kegiatan yang didanai ini hanya 10 (sepuluh) bulan dalam satu tahun anggaran yang berlaku mulai bulan MaretDesember. Hal ini berlangsung selama tahun 20142016, setelah dikonfirmasikan kebijakan ini diambil oleh Pejabat Pelaksana Teknis Kegiatan (PPTK) melalui pertemuan bersama dengan Tim Pengelola BOK Dinas Kesehatan dikarenakan DIPA BOK dari Kantor Wilayah Perbendaharaan terlambat turun ke Pemkot Serang (bulan April). Masalah lain yang ditemukan yaitu adanya ketidaksesuaian pencatatan nama pejabat perbendaharaan dalam DIPA dengan yang diajukan oleh Dinas Kesehatan Kota Serang sehingga ada revisi DIPA yang membutuhkan waktu yang lebih lama lagi, sosialisasi BOK yang diadakan oleh Kementerian Kesehatan juga terlambat begitupun penyerahan Petunjuk Teknis BOKnya (bulan April), dan Surat Keputusan Walikota mengenai Kuasa Pengguna Anggaran (KPA) bagi program BOK pun terlambat sehingga berimbas pada pengesahan DIPA yang terlambat juga.

Selain itu, dalam melaksanakan kegiatan terutama yang berhubungan dengan lintas sektor, menurut keterangan informan di Puskesmas Curug dan Serang Kota terkadang mengalami hambatan pada jadwal kegiatan. Maka dari itu, puskesmas mengambil kebijakan untuk menyesuaikan jadwal kegiatan dengan pihak lintas sektor yang diundang namun untuk laporan pertanggungjawabannya tetap disesuaikan dengan PoA yang diajukan ke Dinas Kesehatan. Kemudian, mengenai durasi kegiatan KIA khususnya kegiatan yang mendukung cakupan K4 dapat dilihat di lampiran. Berdasarkan keterangan informan di Puskesmas, kegiatan KIA ada di setiap bulannya terutama untuk kegiatan Posyandu, namun untuk kegiatan yang lainnya dilaksanakan dalam rentang bulan dan dilaksanakan tidak setiap bulan.

\section{Pembinaan}

Menurut Ivancevich (2005:46) pembinaan sebagai usaha untuk meningkatkan kinerja pegawai 
dalam pekerjaanya sekarang atau dalam pekerjaan lain yang akan dijabatnya segera ${ }^{(9)}$. Berdasarkan temuan di lapangan, pembinaan mengenai manajemen pengelolaan dana BOK berupa bimbingan teknis (bimtek) yang dilaksanakan setahun sekali bagi seluruh pengelola keuangan BOK puskesmas dengan mengundang narasumber dari Kantor Pajak dan Dinas Pendapatan dan Keuangan daerah (DPKD) Kota Serang. Tujuan dari bimtek ini yaitu memberikan pemahaman, informasi dan juga melatih keterampilan pengelola keuangan di Puskesmas mengenai manajemen keuangan dikarenakan banyak pengelola keuangan di Puskesmas yang berlatar belakang pendidikan dari kesehatan.

Kegiatan pembinaan mengenai manajemen BOK lainnya dilakukan oleh Dinas Kesehatan (Seksi Pembiayaan selaku Pengelola BOK Dinkes bekerjasama dengan Keuangan Dinkes dan Pengelola Program) dengan mendatangi langsung puskesmas setiap akhir triwulan sebanyak 4 kali dalam setahun pada tahun 2014-2016. Pembinaan ini berupa pemantauan (monitoring) dan evaluasi terhadap kinerja Puskesmas khususnya pada kegiatan yang berkaitan dengan dana BOK. Hal yang di pantau dan dievaluasi adalah cakupan program, administrasi pembukuan dan keuangan, pencatatan dan pelaporan kegiatan yang dibiayai oleh dana BOK, bahkan Dinkes juga melakukan uji petik secara acak ke Posyandu untuk melihat langsung petugas kesehatan dalam melayani pasiennya.

Pembinaan yang dilakukan oleh Pengelola KIA Dinkes terhadap Bidan Koordinator dan Pengelola KIA di Puskesmas dilakukan dalam dua tahap. Pertama pembinaan dilakukan pada Bidan koordinator dengan mengumpulkan semua bidan koordinator setiap awal tahun sebanyak satu kali untuk membahas cakupan program KIA di tahun sebelumnya serta target cakupan KIA di tahun berjalan. Kedua, pembinaan program KIA dilakukan dengan mendatangi langsung ke Puskesmas dengan Supervisi Fasilitatif (SUFAS) sebagai bentuk pemantauan dan evaluasi terhadap pembinaan dan pelatihan yang telah dilaksanakan sebelumnya. Pada SUFAS ini, dilakukan dengan melihat manajemen Puskesmas dalam melaksanakan kegiatan KIA seperti melihat praktek bidan dalam menghadapi pasien, mengecek pencatatan dan pelaporan bidan, mengecek sarana prasarana KIA yang ada di Puskesmas, kebersihan ruangan serta memberikan informasi sekaligus solusi atas permasalahan yang dihadapi. Namun menurut informan dari Puskesmas, terdapat kekurangan dari pembinaan yang dilakukan oleh Seksi Kesehatan Keluarga sebagai Pengelola Program KIA di Dinkes yaitu mereka tidak memeriksa pencatatan dan pelaporan secara lebih rinci sehingga bidan desa dan pengelola KIA Puskesmas menjadi lalai karena kurangnya pengawasan dalam hal ini.

Pembinaan secara internal juga dilakukan oleh Bidan Koordinator terhadap seluruh staf dibawahnya yang dilakukan sebulan sekali. Pada pertemuan rutin bulanan tersebut biasanya dibahas mengenai permasalahan yang dihadapi oleh setiap pemegang program di Puskesmas berikut target cakupan serta informasi yang berkaitan dengan program ataupun kegiatan di Puskesmas. Namun, dari hasil wawancara terlihat bahwa masih ditemukan kesulitan dalam menghadapi tenaga kesehatan khususnya bidan terutama mengenai kedisiplinan pencatatan dan pelaporannya di empat puskesmas yaitu Puskesmas Banten Girang, Curug, Sawah Luhur dan Serang Kota. Informan mengatakan ada saja bidan yang lalai akan pencatatan, pencatatan tidak rapi ataupun malas mencatat. Pada puskesmas yang cakupan K4nya masih rendah (Puskesmas Curug dan Banten Girang) terlihat bahwa pengawasan dan evaluasi bidan koordinator pada bawahannya masih lemah. Walaupun diadakan pertemuan rutin bagi bidan desa dan bidan puskesmas sebagai pengelola program KIA di Puskesmas oleh bidan koordinator, namun terkesan sekedar formalitas saja. Mengenai mekanisme reward and punishment pun tidak diberlakukan di Puskesmas. Fungsi pengawasan oleh bidan koordinator terhadap pencatatan dan pelaporan dilakukan dengan sekedar menanyakan saja, tidak langsung memeriksa secara mendetail. Akibatnya, petugas kesehatan tidak merasa diawasi dan menjadi lalai terhadap hal ini. Sedangkan pada puskesmas yang cakupannya tinggi yaitu Puskesmas Sawah Luhur dan Serang Kota, pembinaan dilakukan secara rutin setiap bulan dan komunikasi antara bidan koordinator dengan pemegang program KIA dibawahnya berjalan lancar.

Selain itu, ketidakterbukaan pemegang program terhadap kepala puskesmas mengenai masalah yang dihadapi sehingga kepala puskesmas menganggap bahwa kegiatan berjalan dengan baik dan lancar. Salah satu informan mengatakan bahwa kepala puskesmas hanya berorientasi pada infrastruktur puskesmas saja, tidak berusaha untuk merangkul petugas kesehatan dibawahnya an memberikan motivasi serta pengawasannya 
kurang terhadap staf. Seharusnya, sebagai kepala puskesmas yang merupakan pimpinan tertinggi di wilayah kerjanya memiliki kemampuan manajerial yang baik diantaranya mampu memaksimalkan potensi sumber daya manusia di lingkungan Puskesmas dengan lebih merangkul tenaga kesehatan di dalamnya untuk bisa bekerja secara efektif dan efisien.

\section{Cakupan Antenatal K4}

Keterbatasan dana operasional Puskesmas yang bersumber dari dana APBD dalam hal ini Biaya Operasional Puskesmas (BOP) membuat Puskesmas memanfaatkan secara maksimal dana BOK yang ada untuk membantu berjalannya kegiatan yang ada di Puskesmas khususnya untuk kegiatan KIA. Maka dari itu, pada tahun 2014-2016 penyerapan dana BOK di Puskesmas Kota Serang selalu mencapai $100 \%$. Namun daya ungkit dana BOK terhadap program KIA khususnya cakupan kunjungan antenatal K4 masih rendah yaitu dari target $75 \%$ hanya mencapai $68,88 \%$ (2014) lalu naik sedikit persentasenya menjadi $71,27 \%$ (2015) dan turun kembali menjadi $69,45 \%$ (2016). Padahal anggaran BOK untuk Puskesmas dari tahun 20142016 semakin meningkat. Dana BOK yang turun untuk membiayai kegiatan KIA pun terus meningkat dari tahun 2014 sampai 2016 begitupun dana BOK yang dialokasikan untuk mendukung kegiatan K4 di Puskesmas juga meningkat dari tahun ke tahun. Namun, dari 16 Puskesmas yang ada di wilayah Kota Serang, hanya 5 Puskesmas yang berhasil mencapai target cakupan K4 bahkan angkanya melebihi target yang ditetapkan. selebihnya, sebanyak 11 puskesmas yang angka cakupan antenatal K4nya masih dibawah target yang ditetapkan.

Dana BOK untuk kegiatan KIA sebenarnya sangat membantu kelancaran petugas dalam melaksanakan kegiatan KIA. Petugas menjadi lebih semangat dalam melaksanakan kegiatan KIA khususnya dalam melakukan kegiatan di luar gedung yang memang membutuhkan uang transport. Namun permasalahan yang ditemukan di lapangan terutama oleh Puskesmas yang cakupan K4nya masih rendah adalah masalah pencatatan dan pelaporan yang kurang rapi. Bidan masih belum memiliki etos kerja yang baik dan motivasi tinggi dalam melaksanakan tupoksinya. Selain itu tingkat kepercayaan masyarakat yang masih tinggi terhadap dukun disertai pemilihan bidan desa yang merupakan bidan PTT yang berusia muda memperburuk tingkat kepercayaan masyarakat terhadap tenaga kesehatan. Masalah eksternal lainnya kader yang berganti ganti sesuai akibat pergantian dari kebijakan kepala desa yang juga berganti menyulitkan petugas kesehatan dalam berkoordinasi dengan kader karena kader yang sudah dilatih tiba-tiba harus berganti.

\section{Kesimpulan}

Program Bantuan Operasional Kesehatan (BOK) telah meningkatkan anggaran operasional Puskesmas di Kota Serang. Namun, sejak adanya program BOK ini, porsi pembiayaan dari dana APBD untuk kegiatan preventif dan promotif menjadi berkurang. Kenyataan yang terjadi, BOK bahkan menjadi dana utama dalam operasional Puskesmas dalam menjalankan kegiatan terutama di luar gedung. Berdasarkan hasil penelitian ini, ada beberapa kesimpulan penting yaitu:

1. Kompetensi pengelola keuangan BOK Puskesmas masih kurang dan kondisinya selalu berganti hampir setiap tahunnya sehingga menghambat laporan pertanggungjawaban.

2. Bidan di puskesmas memiliki beban kerja yang berat karena mengelola program yang lain sehingga pencatatan dan pelaporan kegiatan lalai dan kurang rapi.

3. Kurangnya evaluasi terhadap pelatihan mengenai KIA yang pernah diselenggarakan sehingga tidak diketahui kemampuan bidan pasca pelatihan.

4. Tingkat kepercayaan masyarakat pada dukun beranak di Puskesmas yang cakupan K4nya rendah masih tinggi.

5. Sarana dan prasarana untuk pengelola keuangan BOK kondisinya sudah tidak laik karena komputer serta printer kinerjanya lambat (kondisi tua) dan banyak virus. Begitupun sarana dan prasarana terutama Posyandu di Kota Serang hampir semua masih menggunakan rumah warga karena tidak memiliki bangunan sendiri. Ketersediaan alat penunjang untuk kegiatan KIA seperti Doppler, USG, juga masih sangat kurang dan dalam kondisi rusak.

6. Pemeriksaan terhadap alat penunjang hanya melihat ketersediaan saja, adapun pemeriksaan rutin ataupun kalibrasi alat kesehatan tidak dilakukan dan dianggarkan oleh Dinas Kesehatan.

7. Dana BOK untuk operasional kegiatan K4 sudah dialokasikan secara proporsional namun daya ungkitnya terhadap cakupan masih rendah bahkan tidak mencapai target 
capaian sebesar $75 \%$ karena petugas hanya berorientasi pada kegiatan yang dibiayai saja.

8. Pencairan dana BOK sering terlambat karena kebijakan di Pemerintah Kota Serang, sehingga menghambat pelaksanaan kegiatan.

9. Mekanisme penyusunan Rencana Usulan Kegiatan (RUK) oleh puskesmas sudah memperhatikan kebijakan BOK yang berlaku dan sesuai dengan Kepmenkes Nomor 128/ Menkes/SK/II/2004 yang memuat Pedoman Perencanaan Tingkat Puskesmas.

10. Proses verifikasi RUK dilakukan oleh Tim Pengelola BOK Dinas Kesehatan dan dibahas bersama dengan memperhatikan indikator SPM, sinkronisasi dengan kegiatan di Dinkes sampai dengan ketentuan proporsi kegiatan yang ada dalam Juknis BOK.

11. Keterlambatan informasi mengenai BOK dan turunnya DIPA dari Kanwil Perbendaharaan mengakibatkan pendanaan kegiatan KIA pada tahun 2014-2016 hanya 10 (sepuluh) bulan dalam 1 (satu) tahun anggaran berlaku bulan Maret-Desember.

12. Pembinaan dan pengawasan yang dilakukan oleh kepala puskesmas dan bidan koordinator di Puskesmas yang cakupan K4nya rendah lemah dibandingkan puskesmas yang cakupan K4nya tinggi.

13. Permasalahan mengenai kader yang berganti akibat kebijakan dari kepala desa yang juga berganti memberikan efek besar. Kader yang sebelumnya sudah dilatih oleh petugas karena diganti menjadi putus kontak dengan bidan desa dan kader yang baru pun harus dilatih kembali.

\section{Saran}

Adapun saran atau rekomendasi yang dapat diberikan peneliti terkait dengan pemanfaatan dana BOK dan kaitannya dengan cakupan kunjungan antenatal K4 di Kota Serang antara lain:

A. Untuk Kementerian Kesehatan:

1. Memberikan pembinaan kepada Pengelola BOK baik di Provinsi maupun Kabupaten/ Kota agar tidak hanya terfokus pada serapan anggaran saja, namun juga perlu melihat capaian program di tiap daerah dengan mempertimbangkan mekanisme reward dan punishment.

2. Melakukan perbaikan atas program BOK terkait sosialisasi mengenai program BOK agar tidak terlambat sampai informasinya ke daerah sehingga petugas kesehatan di daerah tidak terkena dampak karena lambatnya proses ini dan program BOK dapat membiayai kegiatan di Puskesmas selama 12 bulan dalam satu tahun anggaran.

B. Untuk Pemerintah Kota Serang

Meningkatkan alokasi pembiayaan untuk sektor kesehatan khususnya untuk kegiatan preventif dan promotif yang langsung berhubungan dengan masyarakat, karena dana BOK yang diberikan oleh Pemerintah Pusat bukan merupakan dana utama dalam proses penyelenggaraan kesehatan di daerah, dan ini menjadi tanggung jawab Pemerintah Daerah untuk melindungi kesehatan masyarakat di wilayahnya.

C. Untuk Dinas Kesehatan Kota Serang

1. Melakukan evaluasi terhadap pelatihanpelatihan KIA yang pernah diadakan terhadap petugas puskesmas khususnya bidan sebagai pengelola KIA di Puskesmas agar informasi yang sudah diberikan selama pelatihan dapat disebar ke seluruh petugas terkait dan juga dapat dipraktekkan oleh petugas kesehatan.

2. Melakukan pemeriksaan dan kalibrasi secara rutin terhadap alat-alat kesehatan yang ada di Puskesmas agar kinerja alat tetap baik dan akurat.

3. Membuat kesepakatan dengan Puskesmas mengenai waktu pengumpulan laporan pertanggungjawaban dikaitkan pencairan dana BOK dengan menggunakan mekanisme reward dan punishment.

4. Membuat kesepakatan dengan petugas puskesmas mengenai lamanya waktu menjabat sebagai pengelola keuangan BOK di Puskesmas minimal 2 tahun.

5. Pengawasan terhadap Puskesmas terkait pencatatan dan pelaporan dilakukan lebih detail serta bila perlu melakukan uji petik ke lapangan.

6. Memprioritaskan dan meningkatkan kegiatan kelas ibu hamil serta pemeriksaan ibu hamil risiko tinggi diperbanyak disesuaikan dengan jumlah sasaran.

7. Membantu puskesmas berkoordinasi antar lintas sektor agar mengetahui dan memberikan solusi atas permasalahan yang terjadi di wilayah kerja Puskesmas terkait. 
D. Untuk Puskesmas

1. Membuat perencanaan anggaran dari sumber dana JKN (Kapitasi) untuk pembelian alat penunjang administrasi dan pelayanan kesehatan di Puskesmas agar tidak menghambat kinerja petugas dengan melakukan koordinasi dengan Dinas Kesehatan Kota Serang dan Kementerian Kesehatan RI.

2. Membina hubungan lebih baik lagi dengan kader kesehatan agar program kesehatan dapat berjalan dengan lebih baik dan koordinasi masih tetap ada walaupun sudah berganti kader.

3. Memberlakukan sistem reward dan punishment bagi petugas puskesmas yang berprestasi (berkinerja baik) ataupun yang kinerjanya kurang agar lebih memotivasi mereka dalam mengerjakan tupoksinya.

4. Melakukan pemetaan ibu hamil di wilayah kerja bidan desa masing-masing bekerjasama dengan kader agar kontak dengan ibu hamil tidak hilang.

5. Melakukan inovasi-inovasi dalam melaksanakan kegiatan KIA di lapangan agar menarik minat masyarakat untuk memeriksakan kesehatannya pada tenaga kesehatan sehingga cakupan dapat meningkat.

\section{Daftar Pustaka}

1. RI. Undang-Undang RI Nomor 23 Tahun 2014 tentang Pemerintahan Daerah. Jakarta; 2014

2. Gani, A. Kesehatan Masyarakat: Investasi Manusia menuju Rakyat Sejahtera. In T.C Wisal (Ed.) Jakarta: Penerbit Republika; 2011

3. Adisasmito, W. Sistem Kesehatan. Jakarta: PT. RajaGrafindo Perkasa; 2010

4. Kementerian Kesehatan RI. Peraturan Menteri Kesehatan Nomor 82 tahun 2015 tentang Petunjuk Teknis Penggunaan Dana Alokasi Khusus Bidang Kesehatan, serta Sarana dan Prasarana Penunjang Subbidang Sarpras Kesehatan. Jakarta; 2016

5. Kementerian Kesehatan RI. Riset Kesehatan Dasar. Badan Penelitian dan Pengembangan Kesehatan. Jakarta; 2007

6. Kementerian Kesehatan Republik Indonesia. Profil Kesehatan tahun 2015. Jakarta; 2015

7. Kementerian Kesehatan RI. Keputusan Menteri Kesehatan Nomor 128 tahun 2004 tentang Kebijakan Dasar Pusat Kesehatan Masyarakat. Jakarta; 2004

8. Kementerian Kesehatan RI. Buku Pedoman Perencanaan Tingkat Puskesmas. Direktorat Jenderal Bina kesehatan Masyarakat. Jakarta; 2006

9. Ivancevich, John, M., Robert Konopaske \& Michael T. Matteson. Perilaku dan Manajemen Organisasi. Jakarta: Erlangga; 2005 